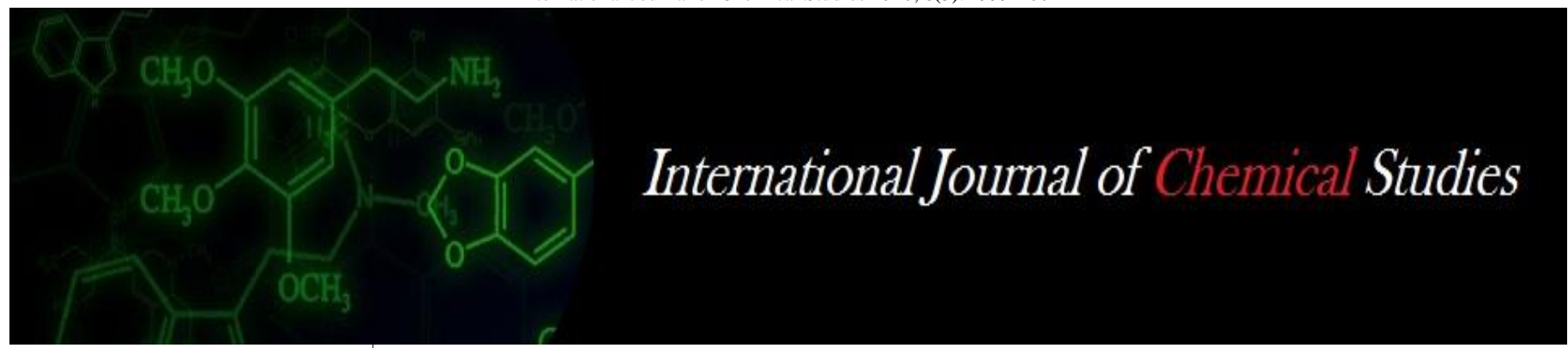

P-ISSN: 2349-8528

E-ISSN: 2321-4902

www.chemijournal.com

IJCS 2020; 8(3): 1999-2001

(C) 2020 IJCS

Received: 14-03-2020

Accepted: 16-04-2020

Chorage CA

Ph.D., Scholar, Department of

Food Process Engineering,

Vaugh Institute of Agricultural

Engineering \& Technology,

SHUATS Allahabad, Uttar

Pradesh, India

Solanke GM

Ph.D., Scholar, Department of

Food Process Engineering,

Vaugh Institute of Agricultural

Engineering \& Technology,

SHUATS Allahabad, Uttar

Pradesh, India

Ranjeet Kale

Ph.D., Scholar, Msc Dairy

Technology, SHUATS,

Prayagraj, Uttar Pradesh, India

\section{Effect of storage conditions on quality and shelf life of Guava Jam}

\section{Chorage CA, Solanke GM and Ranjeet Kalel}

DOI: https://doi.org/10.22271/chemi.2020.v8.i3ab.9502

\begin{abstract}
The work evaluated the storage conditions on the quality and shelf life of guava jam. The prepared jam was carefully poured in steam/ethanol sterilized jam bottles and cocked immediately the jam was allowed to cool and was left for storage. In this study of the Physical, Chemical and Microbial parameters were checked during the storage period. The storage interval was done of 0 days, 15 days, 30 days, and 45 days from the day of preparation of jam. There was significant difference in colour and aroma, texture and sweetness of samples tested. The study concludes that the guava jam was good during the storage study
\end{abstract}

Keywords: Shelf life, storage study

\section{Introduction}

Jam is the product made by a boiling fruit pulp with sufficient sugar to reasonable thick consistency. This method still finds wide application in fruits preservation in spite of modern like caning and freezing because it is simple and economical. This based on the formation of gel by the pectin present in fruit, in properly matured fruits forms a solution with water because some of the pectin substances of the fruits remain in solid portion. In the presence of sugar and acid present in fruit, the pectin sets into jelly or jam. Among proceeds fruits, jam, jellies and marmalade enjoy a predominant position. A large number of units are manufacturing this products to cater the demand of domestic and export markets the products are used as bread spread an in bakery items. They can also be taken with chapati, dosa or similar breakfast food to makes they more appearing. The storage study plays a important role in product development, which is conducted for study of all parameters, quality attributes.

\section{Materials and methods \\ Production of guava jam}

The guava used for the work was purchased from market of Allahabad, Uttar Pradesh. The guava were washed thoroughly with clean water and cut into small sizes. Peel was removed by using peeler. Pulping was done to remove hard seed. Addition of proper proportion of sugar and addition of water in sufficient quantity as per requirement. Boiling was done with continuous stirring. Addition of citric acid and pectin in proper proportion. Judging of EndPoint was done by cooking up to $105^{\circ} \mathrm{C}$ or $68-70 \%$ T.S.S. or by Sheet test. Then filling hot into well sterilized bottles and then cooling was done. Coat of the wax at the top of bottle i.e. on bottle mouth. Capping of bottle or jar was done. Storage of bottle was done at room temperature.

\section{Results and discussion}

Storage study of guava jam

Result of physical and chemical analysis of guava jam

Chemical composition represents the nutritional quality of product. Analysis of proximate composition of Guava jam decides the nutritional profile of prepared jam, as Guava is a novel ingredient. The proximate composition of developed jam was determined in dry weight basis and the results are discussed in Table below.

\section{Solanke GM}

Ph.D., Scholar, Department of

Food Process Engineering,

Vaugh Institute of Agricultural

Engineering \& Technology,

SHUATS Allahabad, Uttar

Pradesh, India 


\section{Chemical analysis of final product}

\begin{tabular}{|c|c|c|c|c|}
\hline Parameters & \multicolumn{4}{|c|}{ Values (\%) } \\
\hline & T0 & T1 & T2 & T3 \\
\hline Moisture & 45.8 & 46.3 & 47 & 48 \\
\hline Protein & 0.33 & 0.26 & 0.28 & 0.27 \\
\hline Ash & 0.32 & 0.39 & 0.38 & 0.37 \\
\hline TSS & 68.5 & 67.5 & 67.5 & 67.5 \\
\hline Acidity & 0.35 & 0.47 & 0.4 & 0.41 \\
\hline Ph & 3.5 & 6.3 & 5.2 & 4.8 \\
\hline Vitamin C (mg/100g) & 25 & 10 & 8 & 6 \\
\hline
\end{tabular}

* Each value represents the average of three determinations
Effect of storage on moisture content (\%) of guava jam The percent moisture content for sample $\mathrm{T}_{0}$ was 45.80 on 0 days, 45.20 on 15 days, 44.80 on 30 days, 44.60 on 45 days. $\mathrm{T}_{1}$ was 46.33 on 0 days, 45.80 on 15 days, 45.10 on 30 days, 44.90 on 45 days. $T_{2}$ was 47.00 on 0 days, 46.800 on 15 days, 46.10 on 30 days, 45.20 on 45 days. $T_{3}$ was 48.00 on 0 days, 47.70 on 15 days, 46.60 on 30 days, 45.60 on 45 days. Similarly on 15 days, 30 days and 45 days shows increase in the moisture content in the sample. The moisture content is also decreasing during storage due to the permeability of packaging material.

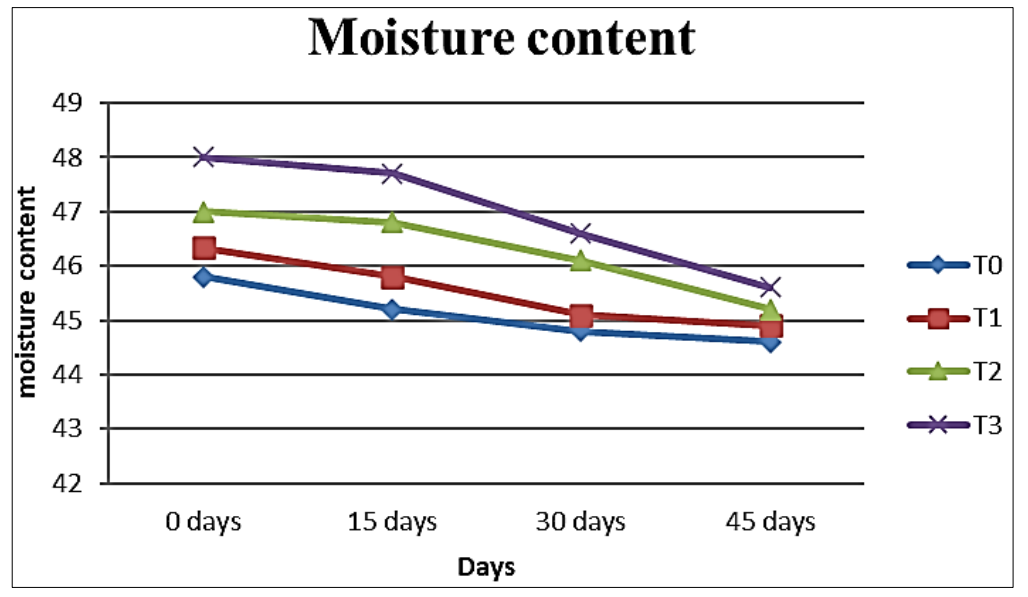

Moisture content (\%) of Guava jam during storage

Effect of storage on vitamin C (mg/100gm) of guava jam The vitamin $\mathrm{C}$ content in the food stuff represents. The vitamin $\mathrm{C}$ for sample $\mathrm{T}_{0}$ on 0 days was 25.0 , on 15 days was 24.5, on 30 days was 24.0 , and on 45 days was 23.5. Vitamin $\mathrm{C}$ for $\mathrm{T}_{1}$ on 0 days was 10.0 , on 15 days were 9.8 , on 30 days were 9.5 and on 45 days were 9.4. Vitamin $C$ for $T_{2}$ on 0 days 8.0 , on 15 days were 7.6 , on 30 days were 7.5 , and on 45 days were 7.3. Vitamin $\mathrm{C}$ for $\mathrm{T}_{3}$ on 0 days 6.0 , on 15 days were 5.8, on 30 days were 5.5 and on 45 days were 5.2. Similarly, for 15 days, 30 days and 45 days shows slight decrease in vitamin $\mathrm{C}$ during storage. The carrot jam is very high in vitamin $\mathrm{C}$ and could be useful against vitamin $\mathrm{C}$ deficiencyrelated ailments like scurvy.

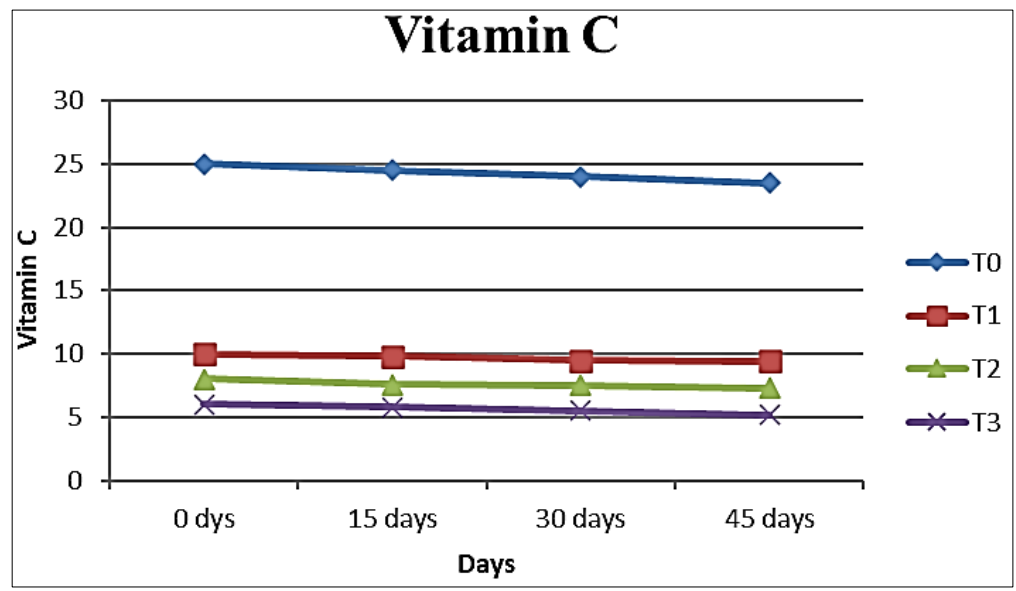

Vitamin $\mathrm{C}$ of guava jam during storage

\section{Effect of storage on protein content (\%) of guava jam}

The protein content of guava jam samples for sample of $\mathrm{T}_{0}$ was 0.33 on 0 days, 0.33 on 15 days, 0.30 on 30 days, and 0.30 on 45 days. $T_{1}$ was 0.26 on 0 days, 0.26 on 15 days, 0.25 on 30 days, and 0.25 on 45 days. $T_{2}$ was 0.28 on 0 days, 0.28 on 15 days, 0.27 on 30 days, 0.27 on 45 days and $\mathrm{T}_{3}$ was 0.27 on 0 days, 0.27 on 15 days, 0.25 on 30 days, and 0.25 on 45 days. Similarly on 15 days, 30 days and 45 days show decreasing in the protein content in the sample. 


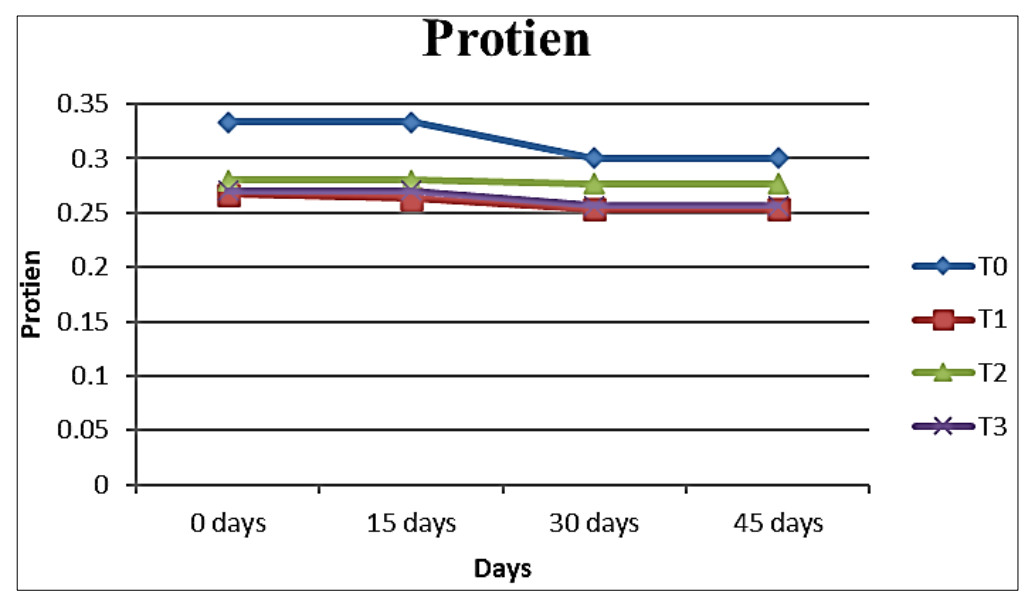

Proteins $(\%)$ of guava jam during storage

\section{Effect of storage on ash content (\%) of guava jam}

The ash content of bottle gourd jam samples for sample of $\mathrm{T}_{0}$ was 0.32 on 0 days, 0.32 on 15 days, 0.31 on 30 days, and 0.31 on 45 days. $T_{1}$ was 0.39 on 0 days, 0.39 on 15 days, 0.38 on 30 days, and 0.38 on 45 days. $T_{2}$ was 0.38 on 0 days, 0.38 on 15 days, 0.37 on 30 days, 0.37 on 45 days and $\mathrm{T}_{3}$ was 0.37 on 0 days, 0.37 on 15 days, 0.36 on 30 days, and 0.36 on 45 days. Similarly, on 15 days, 30 days and 45 days show decreasing in the ash content in the sample.

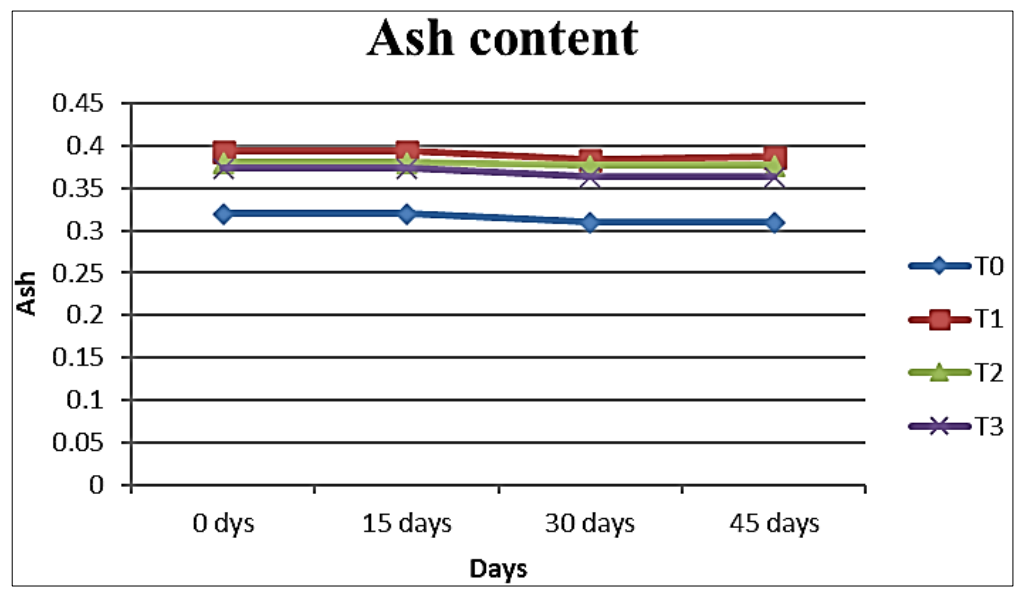

Ash content (\%) of Guava jam during storage

\section{Conclusion}

It was found that quality of guava jam which was stored was in good conditions after the storage of 45 days and was acceptable. The packaging material plays a great role in the storage study period.

\section{References}

1. AOAC. Official Method 963.19 "Official Methods of Analysis"., 18th Edition. Horwitz W, George LW (eds.). Association of Official Analytical Chemists, Maryland, 2006.

2. Blitz HD, Grosch W. Sources of Natural Phenolic Antioxidant. Food Chemistry Springer Berlin, 2004, 6973.

3. Coulate TP. The Chemistry Food and its components, 2nd ed. Cambridge, 1989.

4. Isabel DW, Willisam S. Making Jams, Marmalades, Preserves and Conserves University of Minnesota Extension School, 1990.

5. Iwe MO. Handbook of Sensory Methods and Analysis. Rejoint Communication Services Ltd Uwani Enugu, 2002, 40-83.

6. Manuel Octavio Ramírez-Sucre., and Jorge Fernando Vélez-Ruiz Effect of formulation and storage on physicochemical and flow properties of custard flavored with caramel jam. Journal of Food Engineering. 2014; 142:221-227.

7. Marjan Javanmard, Johari Endan. A Survey on Rheological Properties of Fruit Jams. International Journal of Chemical Engineering and Applications. 2010; 1(1):31-37.

8. Massimiliano Renna, Bernardo Pace, Maria Cefola, Pietro Santamaria, Francesco Serio and Maria Gonnella Comparison of two jam making methods to preserve the quality of colored carrots, Food Science and Technology. 2013; 53:547-554. 